\title{
An assessment on how China Foreign Direct Investment Policy (FDI) Stimulate Development in African Countries: the case of Tanzania
}

\author{
Amran Said Suleiman, Sahim Abdalla Juma \\ 1st author's affiliation, School of Public Affairs, University of Science and Technology of China, Hefei, 230026, \\ China \\ amran@mail.ustc.edu.cn \\ 2nd author's affiliation, School of Public Affairs, University of Science and Technology of China, Hefei, 230026, \\ China \\ sahim@mail.ustc.edu.cn

\begin{abstract}
In this paper we have reviewed a case study which assess how China Foreign Direct Investment Policy (FDI) Stimulate Development in African Countries: The Case of Tanzania. FDI significantly increase the domestic in Africa both in monetary terms and also increase the gross of domestic product (GDP). Furthermore, FDI is an approach of changes the experiences and skills in different sectors like technology, market, infrastructures, education etc. African countries remains as recipient of the FDI inflows but still the out flows are very low especially in East African countries (Tanzania is one among the East African Countries). Also suggest that it is the time now African leaders to rethink again about their investment strategy to ensure other sectors like education, technology and infrastructures. Thus, provides more room for investors in those particular areas. In addition to that, the leaders must change their economic policy to attract more investors to invest in different sectors.
\end{abstract}

Key words: FDI, Africa, development

\section{Academic Discipline And Sub-Disciplines}

Economics, finance, public policy;

\section{SUBJECT CLASSIFICATION}

Economic Policy - Foreign Direct Investment (FDI)

\section{TYPE (METHOD/APPROACH)}

Literary review and analysis

\subsection{Introduction}

FDI plays the significant role as a source of financing for a lot of developing countries (Adams, 2009). In 1980s to1990s in East Africa experience a great economic changes seized in power; because of the economic liberalization and privatization adoption policies in which these countries with respected governments tried to use the private sectors as it is the major economic growth engine. This economic restructuring change the government efforts towards the need for capital, need of new technological change and skills to be injected in private sectors to make the sector manage the more incentive and FDI attraction (Senkuku, \& Gharleghi, 2015). Kenya was the one in East African country where investors choice as a prime seeking to launch a presence in Eastern and Southern Africa in the 1960s and 1970s, poor and unprofitable economic policies and unreliable efforts at structural reforms, growing problems of corruption and governance, and the weakening of public services have discouraged the development of FDI since the 1980s (UNCTD, 2005). The government of Uganda has reversed earlier economic policy in a directive on destruct of their economy and provides an extra opportunity for inverters and investment climate. The changes of its economic policy since 1991 have been satisfied by a significant and actually satisfying stimulation of domestic and foreign investment. The Government needs to take a number of activities to certify that; this revival is sustained and that Uganda realizes its undoubted potential to attract much more FDI (UNCTD, 2000). Furthermore, FDI makes to country's economic growth and integration into the world economy is extensively recognized. For this reason Tanzania has took a significant effort over the past three decades to expand investment climate with a view to attracting more FDI, aiming to improve the economy (B.O.T, 2013). Indeed, making great effort to attract more FDI inverters and there is indication that FDI is actually contributing the development growth. There are remarks that aspect recent improvement in the economic growth to the rapid increase in FDI inflows particularly in the second half of 1990s. But more concerns were also highly regarding the social impact of FDI on the poor and local investors in the country (CUTS, 2003).

\section{How Africa Benefited in FDI}

According to many literature shows that Africa Day after day the FDI inflows in Africa is increasing after a dip in 2013, the flow of FDI funding into Africa recovered sharply. During 2014, FDI inflows to the continent more than doubled to US $\$ 127.9 \mathrm{~b}$ (from US $\$ 54.2 \mathrm{~b}$ ) driven by several large deals. Investment per project averaged US $\$ 174.5 \mathrm{~m}$, 
International Journal of Management and Information Technology againstUS $\$ 67.8 \mathrm{~m}$ in 2013 and US $\$ 169.9 \mathrm{~m}$ in 2008, and the previous peak. The improvement was determined by great, capital-intensive energy extraction and real estate schemes.

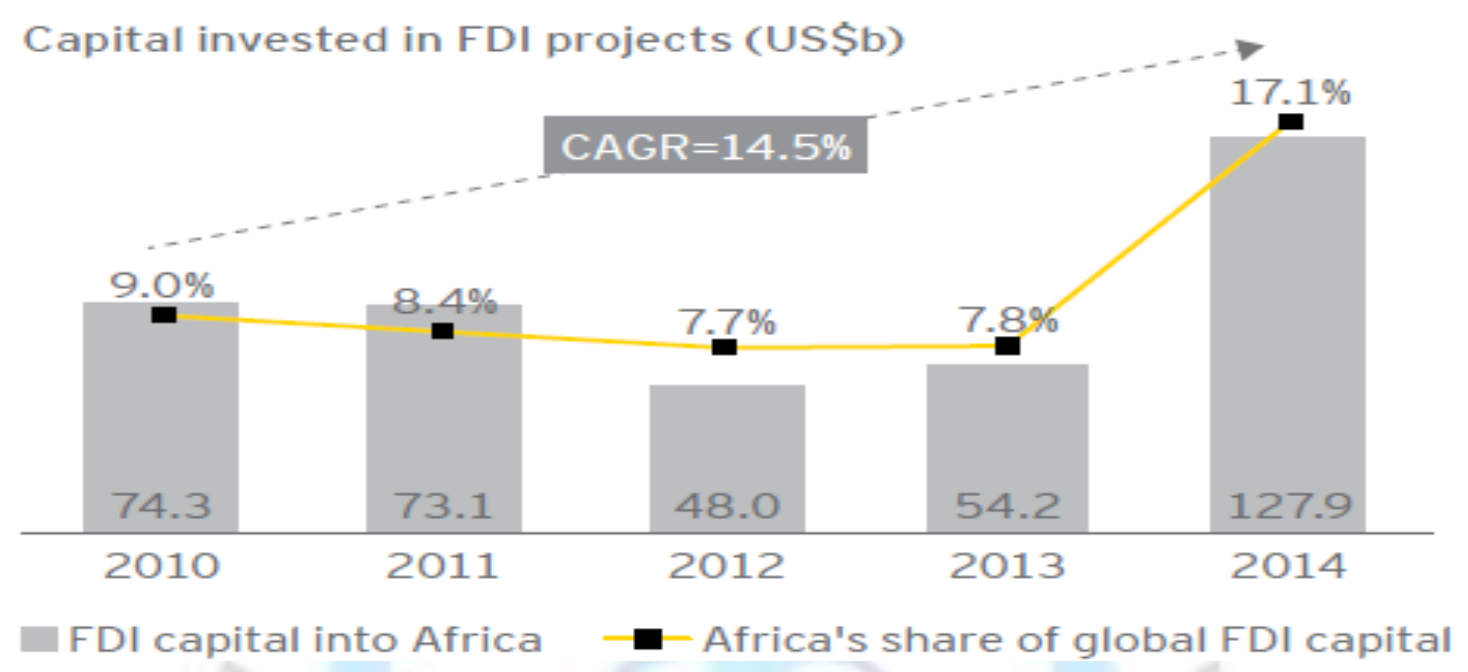

Figure 1: Source: Y, E. (2015). EY's attractiveness survey Africa

The data show that FDI inflows in Africa decrease in the years of 2013 and 2014 remains in 54 US billions of dollars while in 2012 was in 56 US billions of dollars.

Also through FDI jobs are rises and reduce the problem of unemployment. In 2014 FDI projects announced which create 188,400 jobs in Africa 76200 more than in 2013. Indeed, Africa's share of jobs created worldwide by FDI rose from $5.9 \%$ in 2013 to $8.7 \%$ in 2014. However, since a job-creations outlook, African FDI remains a poor player. Although Africa's population is increasing fast and unemployment is high, its FDI projects provide more capital than employment opportunity. Figure 1

Figure: 1 Show Job Creation by FDI Globally

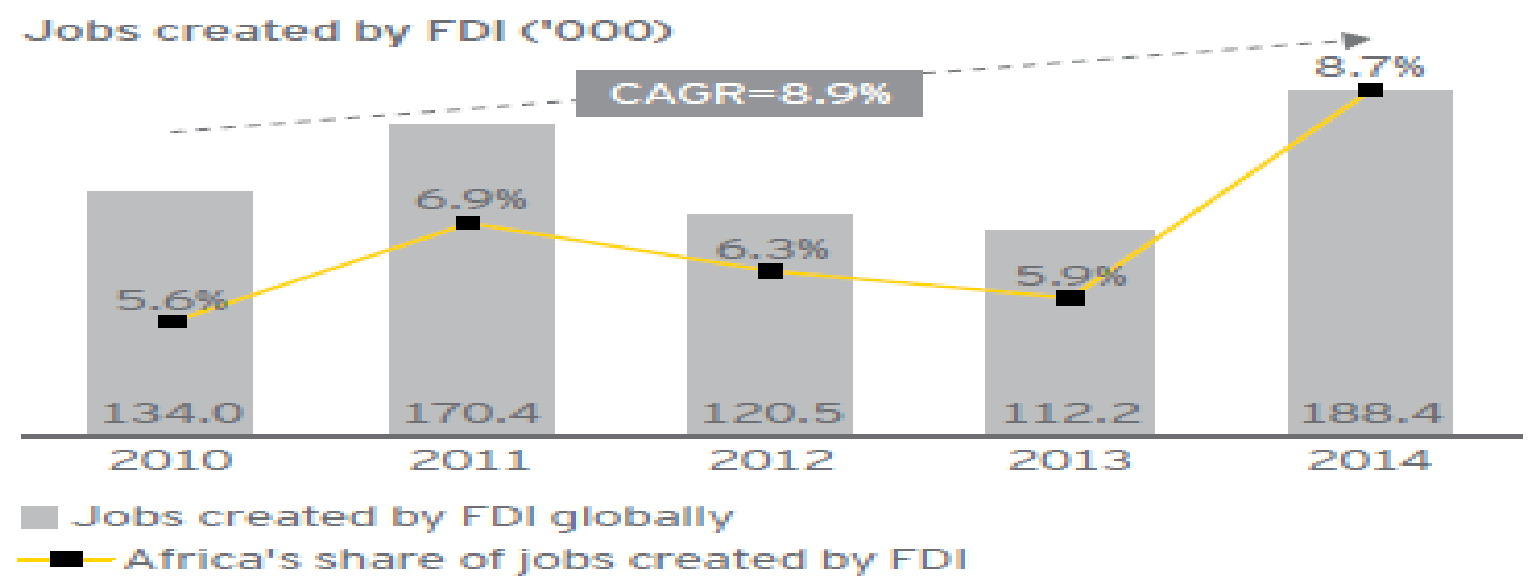

Figure 2: Source:Y, E. (2015). EY's attractiveness survey Africa

In 2014, Africa attracted about $17.1 \%$ of worldwide FDI inflows (only Asia-Pacific performed better) but got only $8.7 \%$ of jobs. Its increased share of global FDI jobs in 2014 is an improvement, but a much bigger rebalancing is needed (EY's, 2015).

The continent more than doubled its share of overall FDI flows, from $7.8 \%$ in 2013 to $17.1 \%$ in 2014 . That made it the second biggest recipient of capital investment during the year, from sixth in 2013, and the fastest-growing target for FDI funding. Also the data reveal that how Africa benefited from FDI and during $2000 \mathrm{FDI}$ inflow is about 40.4 US dollars but up to 2013.Futhermore, the data also reveal that it's about 192.0 US billion dollars and most based on Portfolio, Official Development Assistance Investments and remittances figure, 2. 


\title{
Foreign Investments (both Direct and Portfolio) now largest source of Capital flows
} to Africa (US\$b)

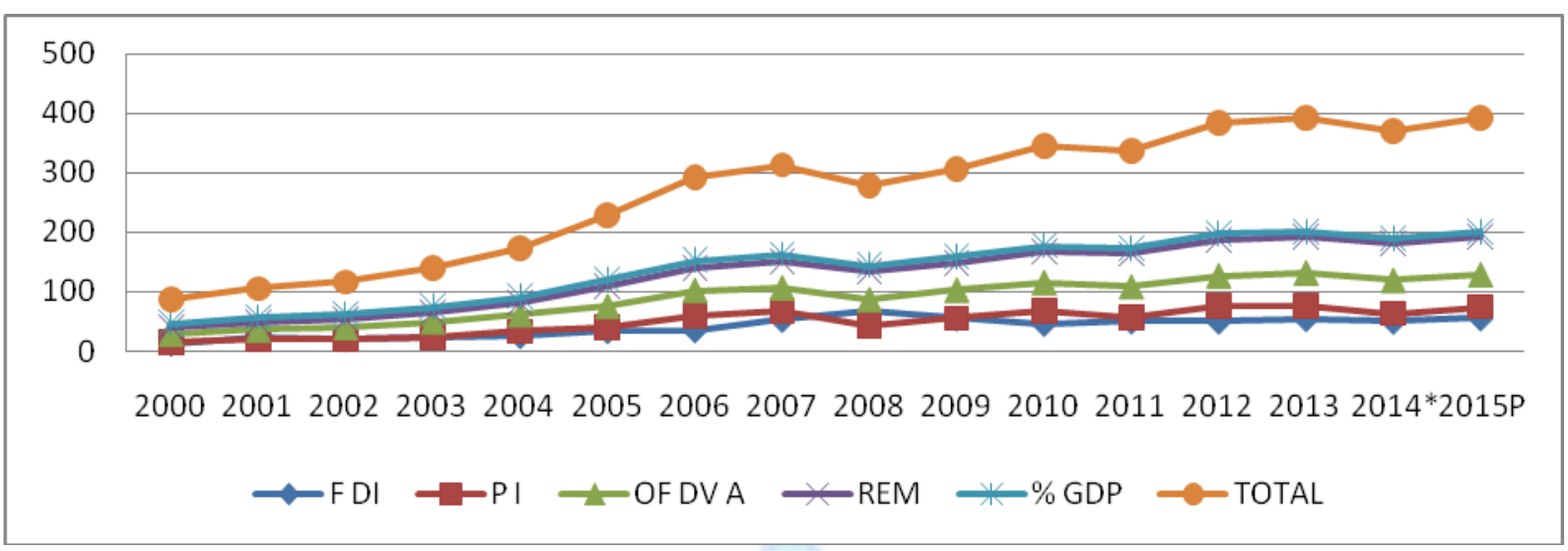

Graph 1: Foreign Investments (both Direct and Portfolio) now largest source of Capital flows to Africa (US\$b)

\section{Source: African Development Bank, OECD and UNDP.}

\author{
${ }^{*} \mathrm{E}=$ estimate, $\mathrm{P}=$ projection
}

$\mathrm{FDI}=$ Foreign direct investment, $\mathrm{I}=$ Portfolio investment, OF DVA=, Official Development Assistance, REM = remittances, $\mathrm{GDP}=$ gross domestic product

\section{Review from EY's Attractiveness Survey Africa 2015}

In 2014 estimation shows about 181.1 US billion dollars; this is due to the fact that it decreases because of some political issues in few countries like the chaos in South Africa when natives killed some of the foreigners people blame due to take their job. Indeed, the case of Burundi as well as Zimbabwe. Many investors during the coming of the election period they tried to reduce some of their business until the finish of the election. For example in Tanzania also during the general election of 2015 so somehow affect the FDI investment. On the other, hand the projection show that it will be increased by up to 191.5 US billion dollars in this year to $2015 / 2016$.

\section{China FDI and African Economy}

China has playing a great role and become a development model for African and as another basis of trade and investments from African traditional development partners. The influence of China in Africa economies has been varied where depending much in the sectoral composition of the country's production. Generally, China increased engagement in African to generate the important gains in Africa economies. But, more analysis is required to enumerate the benefits and problems, and to design the policies necessary to maximize the changes and impact of China. One thing that is very important to consider is that reaping the full benefits from Chinese trading and investment will require substantial improvements in governance in African Economies (Renard, 2011). Indeed, numerous states owned banks have supported China's presence in Africa. For example China initiated Exim Bank (China Export-Import Bank) in 1994 to support Chinese exports goods and foreign direct investment (FDI) precisely in the infrastructure sector. Roads, power plants, pipelines, telecommunications, etc. (Wang, 2007). Bank support investment projects and has less risk-sensitive to the private banks. Exim Bank in Tanzania (Zanzibar) support the Revolution Government of Zanzibar about 200 million USD loans for the construction of the new port in Zanzibar as well as the second investment project for the expansion of terminal two Abeid Amani Krume International Airport.

\section{China FDI policy and Tanzania Economy}

Basically, China's relations with African countries, and definitely its global economic strategy, have been shaped by the need to obtain energy resources to support their economic development. On the other side, political considerations have also played a significant role (Renard, 2011).China policy concentrated much on the industrial processing. China possesses relatively advanced technology in the fields of electronics and equipment construction, textiles and garments, and building resources. Indeed, based on the infrastructure and real estate development. For example China helped the United Republic of Tanzania and Zambia to build an important cross-border railway line (TAZARA) from Dar es Salaam to Kapiri Mposhi in Zambia's Central Province in Zambia since 1978 the project is about 1,860 kilometer(1,160 mi) -long line, begun in 1970 and finished in 1975. At the cost of US \$500 million in an interest-free loan to build, the TAZARA was the largest single foreign-aid project undertaken by China (Jansson, Burke, and Hon, 2009).Also; they pay attention natural resources to support African economic growth. Africa is very rich in natural resources so China tries to secure access to natural resources mainly petroleum and high-value minerals can provide such resources (UN, 2007; Chen and Jian, 2009). 
International Journal of Management and Information Technology

\subsection{Tanzania FDI policy and its Development}

Tanzania is the one among the developing countries take effort to change its economic policy since 1967 after the Arusha Declaration. Since that time many investors are much interested to invest in Tanzania especially when the second phase President Ali Hassan Mwinyi during 1980's when initiated and diversify its economic policy. This deed generated and opens room for the rise of FDI inflows into Tanzania. For example in 1999 FDI inflows increase from 2418 million USD to 3776 million USD in 2001. This investment distributed into the manufacturing goods to $33 \%$, agriculture $7 \%$ as well as mining and quarrying for $28 \%$ (Senkukuand Gharleghi, 2015). But, day after day there is some improvement. For example in Africa during $2012 \mathrm{FDI}$ inflows improved to $3.4 \%$ from $2.5 \%$ recorded in 2011, while that of global inflows remained at $0.1 \%$.

Table: 1 FDI Inflows in Africa, 2008 - 2012

\begin{tabular}{|l|c|c|c|c|c|}
\hline & $\mathbf{2 0 0 8}$ & $\mathbf{2 0 0 9}$ & $\mathbf{2 0 1 0}$ & $\mathbf{2 0 1 1}$ & $\mathbf{2 0 1 2}$ \\
\hline Global (Billions of USD) & $1,816.3$ & $1,216.5$ & $1,408.5$ & $1,651.5$ & $1,350.9$ \\
\hline Africa (Billions of USD) & 58.9 & 52.9 & 43.6 & 47.6 & 50.0 \\
\hline Tanzania (Billions of USD) & 1.3 & 0.9 & 1.8 & 1.2 & 1.7 \\
\hline Tanzania's share in Africa (\%) & 2.2 & 1.7 & 4.1 & 2.5 & 3.4 \\
\hline
\end{tabular}

Table: 1 FDI Inflows in Africa, $2008-2012$

Source: World Investment Report 2013 and Tanzania Investment Report, 2012

FDI inflows to Tanzania increased by $46.4 \%$ to USD 1,799.6 million in 2012 from USD 1,229.4 million recorded in 2011 (Table 1). The upsurge was mostly on account of equity and investment fund shares as well as reinforcement of earnings which together accounted for about $100 \%$ of the total inflows of FDI. Some activities which are very much attracted by investors and more flows were mining and quarrying, manufacturing, gas and electricity; and finance and insurance (BOT, 2013).

\subsection{Growth Domestic Products (GDP)}

GDP in Tanzania expanded 7.1 percent year-on-year in the last three months of 2015, higher than a 6.3 percent growing in the previous period and 4.1 percent a year earlier. Information activities and communication recorded growing faster (23.0 percent), followed by public administration and defense (19.7 percent).While financial and insurance took (13.6 percent) and lastly mining and quarrying (10.6 percent) Figure 3

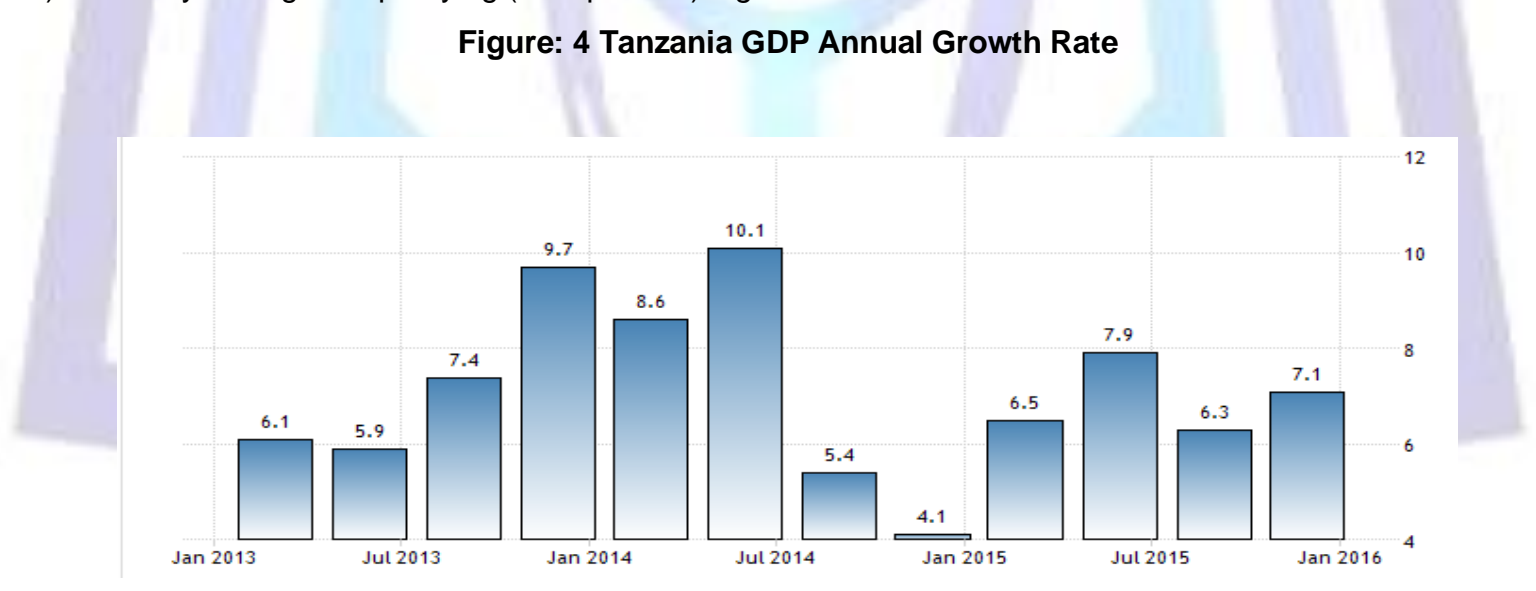

Figure: 4 Tanzania GDP Annual Growth Rate

Source: Tanzania nationalbureau of statistics (NBS) retrived 03-03-2016

In contrast, with other sectors namely utilities ( 0.1 percent) at lower rates, accommodation ( 1.4 percent), food services ( 1.7 percent) and agriculture (2.6 percent) respectively. Considering full 2015 , the economy advanced 7.1 percent, higher than 7 percent in 2014. Annual Growth Rate in Tanzania, the GDP average 6.72 percent from 2002 until 2015, reaching an alltime high of 12.40 percent in the first quarter of 2007 and a record low of 2.60 percent in the third quarter of 2009. GDP Annual Growth Rate in Tanzania is reported by the National Bureau of Statistics (NBS) Tanzania (www.tradingeconomics.com, retrieved on 03-03-2016).

\section{Why China Invested in Africa?}

There is a negative notion that many of the African countries are unstable and their governments in systematic political risk analysis when embarking on foreign projects in Africa. Thus many countries they prefer to provide aid in necessary weighting up of opportunities against potential losses when deciding whether to proceed with such a venture in the region. 

Indeed, Africa does not attractive the FDI due to many reasons; namely poor infrastructure is very serious in several African countries as well as potential domestic market which hinders business growth and efficiency. Also, negative perception of prospective foreign investors that the region has a large unskilled labour force, high quality goods and well educated skilled and discipline labour force is required to maintain the competitive edge of the most of Multi National Cooperation's (MNCs) in the global market place. (Lugt, et al, 2011) on the other hand, Chinese government criticizes this wrong notion about Africa and tried to invest because they feel that they do not get much competition. Thus, often less competition should be considered as well as an important trigger for these Chinese investors.

China's appeared as the world's most prominent growing industrial economy is current to transform the international economic and financial landscape. The country is now the world's fourth main exporter, providing upwards of $6 \%$ of worldwide exports of goods. It is the only main destination for FDI. Basically, its impact will increase further with time: majority forecasts suggest that its economy will grow by as much as $10 \%$ per annum and that it will continue adding 20 million workers annually to its modern, export-oriented manufacturing sector for several decades to come (Eichengreen andTong, 2005, UN, 2007).

Chen, Chang and Hang (1995) in their studies found that FDI has been absolutely connected with economic growth, and upsurge of total fixed benefit investment in China. Also FDI has also forced and growing number of domestic manufacturers to contest globally. Indeed, FDI in China is still an ongoing process that positively and absolutely stimulates the Chinese economy. While initial FDI China is observed, and these are bound to contribute toward the success of its recent economic reforms.

\section{Conclusions}

It is limited comprehensive data to show how the contribution of China in FDI to the socio economic development. Several data show that FDI contributed greatly the economic growth of the recipient country. FDI significantly increase the domestic in Africa both in monetary terms and also increase the gross of domestic product (GDP). Furthermore, FDI is an approach of changes the experiences and skills in different sectors like technology, market, infrastructures, education etc. The data also shows those African countries remains as recipient of the FDI inflows but still the out flows are very low especially in East African countries. In spite of that mostly of inflows of FDI not only in China but other counties based on the natural resources like oil, gas and other minerals. Precisely FDI contributes the economy of the country in Africa and both benefited even though not in the equal weight. It is the time now African leaders to rethink again about their investment strategy to ensure other sectors like education. Technology and infrastructures are provided more room to investors in that particular area. In addition to that, the leaders must change their economic policy to attract more investors to invest in different sectors. Indeed, African regional cooperation also provides incentive and some exemption of the member's state to manage the investment in the continent.

\section{ACKNOWLEDGMENTS}

We would like to give our thanks to our school for public affairs at University of Science and Technology of China who have showing their support while we conduct this research, Our thanks also goes to Chinese Scholarship Council of China for financial support to first author and Chinese Academy of Science (CAS), China and The Third World Academy of Science (TWAS) for the financial support to second author.

\section{References}

1. Adams, S. (2009). Foreign Direct investment, domestic investment, and economic growth in Sub-Saharan Africa. Journal of Policy Modeling, 31, 939-949.

2. Chung Chen, C, Chang, L. And Zhang, Y. (1995). The Role of Foreign Direct Investment in China's Post- 1978 Economic Development. World Development, Vol. 23, No. 4, pp. 691-703, 1995, Great Britain.

3. Eichengreen, B and, Tong, H (2006). Fear of China. Journal of Asian Economics 17 (2006) 226-240.

4. Jansson, J, Burke,C and Hon, T.(2009) Patterns of Chinese investment aid and trade in Tanzania, A briefing paper by the Centre for Chinese Studies, University of Stellenbosch;

5. Renard, Mary-Francoise (2011), China's Trade and FDI in Africa, Series N 126, African Development Bank, Tunis, Tunisia.

6. Sanne van der Lugt, S.V, and Hamblin, Meryl Burgess, M and Schickerling, E.(2011). Assessing China's Role in Foreign Direct Investment in Southern Africa, Centre for Chinese Studies at Stellenbosch University, Oxfam Hong Kong

7. Senkuku, A. M., Gharleghi, B. (2015). Factors Influencing Foreign Direct Investment Inflow in Tanzania. International Journal of Business and Management, 10, 48-56.

8. Suleiman, N.N, Kaliappan,, S.R and Ismail,N.W (2013). Foreign Direct Investments (FDI) and Economic Growth: Empirical Evidence from Southern Africa Customs Union (SACU) Countries. Int. Journal of Economics and Management 7(1): 136 - 149 (2013), 7(1): 136 - 149 (2013). ISSN 1823 - 836X

9. Wang Jian-Ye (2007), “What's Drives China's Growing Role in Africa?”, IMF Working Paper. International Monetary Fund, Washington, D.C.

10. B.O.T. (2013). Tanzania Investment Report 2013. Foreign Direct Investment, Tanzania 
nternational Journal of Management and Information Technology 11. CUTS. (2003). Investment Policy in Tanzania- An Agenda for Action, Printed by: Jaipur Printers P. Ltd., Jaipur 302 001C India ISBN 81-87222-98-0

12. UNCTD (2005). Investment Policy Review Kenya. New York and Geneva: United Nations

13. UNCTD (2000). Investment Policy Review Uganda. Geneva: United Nations

14. Y, E. (2015). EY's attractiveness survey Africa 2015: Emerging Markets Center.

15. www.nationalbureau of statistics (NBS) retrived 03-03-2016 7:10pm

16. www.tradingeconomics.com, retrived 03-03-2016 7:09pm 